\title{
SHARE KNOWLEDGE, PARTICIPATE IN OPEN EDUCATION AND CREATE OER
}

Ana Nobre - Laboratório de Ensino a Distância e eLearning (LE@D), Universidade Aberta / Portugal

\begin{abstract}
This article focus on the presentation of a curricular unit of an online master's course and its innovative pedagogical design: share, participate in Open Education and its integration of Open Educational Resources towards an opening movement for knowledge democratization. Thus, are analyzed pedagogical strategies and their impact in students learning process to determine the importance of this movement for an effective and successful learning process. Based on the perspectives of teachers and students(Portuguese, Brazilian and Africans), in order to understand the dynamics of using and sharing online resources in their pedagogical practices, we signal the need to develop innovative open educational practices from the point of view of (co) authorship for the integration of Open Educational Resources in online education and we highlight the students' products resulting from this process and reveal the achievements that this philosophy can reach.
\end{abstract}

Keywords: Teaching, Learning, Open Educational Resources, Open Education

\section{INTRODUCTION}

Even today, dominates pedagogically a teaching model centered on the teacher and the one-way transfer of knowledge, in which learning becomes less the autonomous acquisition of knowledge and more for the development of specific curricular skills and other cross-cutting, which makes it a priority adequate organization and planning of Teaching and Learning Process (TLP). This way of conducting the process results in curricula and teachers unprepared to develop a self-regulated learning (ZIMMERMAN, 2002; ZIMMERMAN; BONNER; KOVACH, 1996).

However, there are already movements that begin to question and to review the way of learning and teaching. These initiatives is observed that traditional education, which placed the teacher as the center of the teaching-learning process, it is exceeded by the quality of teaching and learning, which adopts self regulation of student as the

Educação, Psicologia e Interfaces, Volume 4, Número 3, p. 1-18, Julho/Setembro, 2020.

ISSN: 2594-5343. DOI: 10.37444/issn-2594-5343.v4i3.257 
foundation of innovation in the area (GOMES; TAVARES, 2000; MACHADO; ALMEIDA, 2000; ROSARIO, MOURAO; SALGADO, 2006; SANTIAGO, 2000).

In 2013, the European Commission presented an action plan which addresses the challenges that schools and higher education institutions face in adapting to new technologies and integrate them in their teaching methods. "Open the World Systems of Education" is the motto to promote innovation and digital skills in schools and European universities.

In this field, called the movement of open access or free access, we will place our practices with regard to teaching and research. This movement aims to promote free and open access to scientific and academic literature, promoting a change in the work carried out by researchers and institutions.

Given the importance of understanding the specific role of teachers, analyze their practices and the impact on student learning in this framework and in the context of this global movement in terms of Open Educational Resources (OER) and educational practices, in the first part of this article will be addressed the theoretical concepts that underlie this experience. The second part will be presented examples of resources and activities of the pedagogical design of a curricular unit (CU) of an online master's degree and, in the third part, the testimony of two students on the impact of this teaching method and this movement for their learning processes. The findings indicates the need to develop innovative educational practices from the point of view of teaching (co)authored for integration of OER in online education.

\section{THEORETICAL CONTEXTUALIZATION}

Research on the process of teaching and learning reveals that to get good results we should take into account the following components: i) setting goals; (ii) time management; (iii) definition of learning strategies; (iv) monitoring; (v) adapted causal attributions; (vi) resources searching; (vii) beliefs of self-efficacy; and (viii) motivation. Other studies (SCHUNK; ZIMMERMAN, 1994, 1998) indicate that the learning level of students varies according to the presence or absence of each of the key components above, when compensating for individual differences is performed effectively. Thus, the learning strategies that allow the acquisition and retention of new information can be more

Educação, Psicologia e Interfaces, Volume 4, Número 3, p. 1-18, Julho/Setembro, 2020.

ISSN: 2594-5343. DOI: 10.37444/issn-2594-5343.v4i3.257 
important in mental skills when we verify a positive relationship between their quality and academic performance.

Rosário, Núñez and Pienda (2006) defines learning strategies as a guiding systematic plan of school work to achieve the desired goals. These strategies, according to Rosario (2004), cover the behavior and thoughts used by students during the learning process in order to influence their coding process.

We affirm with Paiva (2007), different students show diverse ways of learning depending on the method or strategy they adopt. Some have a more dynamic and active role in the acquisition of knowledge (contributing ideas in rooms or virtual classes, doing discuss views, read in books and articles themselves) and others take a passive learning (listening to the teacher and colleagues discuss without intervention or visible effort). The literature states that learning should involve the use of general and specific learning strategies to achieve the educational goals set from self efficacy perceptions (ROSÁRIO; NÚÑEZ; PIENDA, 2006; ZIMMERMAN; BONNER; KOVACH, 1996). Students who regulate their own learning have the ability to, on the one hand to exercise control over the different dimensions of the learning process, including the selection, combination and coordination of cognitive strategies in a particular context; and, second, to channel resources to the different aspects of the teaching and learning process (Rosario et al., 2006).

Therefore, the importance of sharing knowledge and the role of higher education systems in today's global knowledge economy has been recognized over the last few years, initiatives and organizations all over the world. However, this has been a movement that has elapsed a bit on the margins of political decisions, both at Commission level and at the level of European countries in general. To help launch the initiative, the European Commission announced a new Web site, Open Education Europe, which allows students, professionals and schools to share educational resources open to unrestricted use.

In the field of education itself, and more particularly to higher education, many institutions have incorporated the technology in its management, administration and educational programs: investment in LMS platforms (learning management systems), continuous access to library resources, electronic/digital equipment, among other examples. Without questioning its benefits to education and to students in particular, it is noted that these investments have taken place in the context of the dominant educational

Educação, Psicologia e Interfaces, Volume 4, Número 3, p. 1-18, Julho/Setembro, 2020.

ISSN: 2594-5343. DOI: 10.37444/issn-2594-5343.v4i3.257 
model centered on the teacher and the one-way transfer of knowledge. However, the development of new distance education models network reveals the need for changes in the traditional paradigm, in particular for higher education, whose potential beneficiaries are located all over the world, hence the need to "open education" (EUROPEAN COMMISSION, 2013).

A set of initiatives that has had echo in the open education movement is related to the theme of OER and are considered basic in the creation of educational opportunities for innovation. Still, several studies and the authors (CONOLE, 2012; WILEY; HILTON, 2009; YUAN; POWELL, 2013; EHLERS, 2011; MULDER, 2011) confirm that, over a decade after the start of OER movement or the traditional business model of higher education, or approaches in pedagogical practices have undergone major changes. Ehlers (2011) states that, despite the increasing availability of OER, supported by a growing number of initiatives and projects, their use has not had the same evolution. The author admits that this is because there's still an emphasis on expanding access to digital content, regardless of whether it will support the educational practices and the promotion of quality and innovation in teaching and learning. Thus, it suggests that to provide educational opportunities for all citizens, to widen the focus beyond access, to include 'innovative open educational practices' (EHLERS, 2011).

In this process, teachers play a key role. In a report presented to UNESCO entitled "Open Educational Resources - Open content for higher education," Albright (2005) recognizes the following:

The key component of OER is the educational content, and the essential source is the instructor who provides that content and agrees to make it freely and openly available. Whether OER is driven by 'top-down' institutional systems or 'bottom-up' individualized initiatives, the higher education faculty member is pivotal to creation of the educational substance. Securing the backing and involvement of faculty members is therefore a major priority for institutions involved in OER development. (ALBRIGHT, 2005, p. 7).

Therefore, the educational level, teachers (regardless of their more or less active roles in technology co-development of OER) have the challenge of creating possibilities of integration of educational technology network in the teaching and learning process and also in research activities. Thus, openness and flexibility are both conceptual and operational order. In other words, this means that in addition to the theoretical discussion

Educação, Psicologia e Interfaces, Volume 4, Número 3, p. 1-18, Julho/Setembro, 2020.

ISSN: 2594-5343. DOI: $10.37444 /$ issn-2594-5343.v4i3.257 
about a student centered learning and the open education principles concrete practices are needed.

\subsection{Presence of OER in the pedagogical design of a curricular unit - teaching outlook}

The knowledge and the appropriation of innovative ways of teaching / learning network implies flexibility and diversification of educational resources and activities options. It is an important point for the support of two-way communication around the curriculum content and educational practice in research communities focusing on the presence of the school (Figure 1).

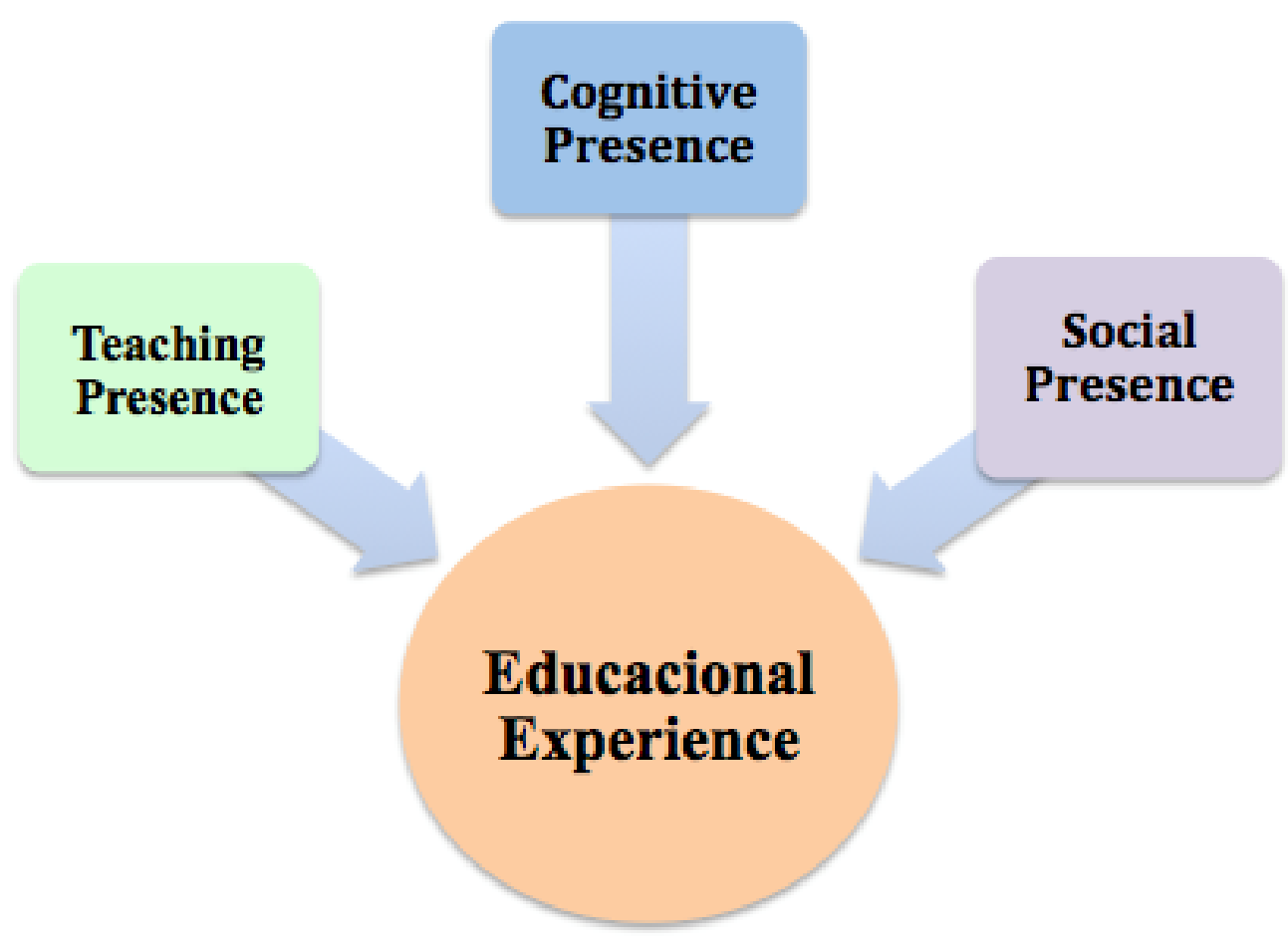

Figure 1: Adapted from Community of Inquiry - Elements of an educational experience. Source: Garrison, Anderson e Archer (2000, p. 88).

The teaching presence is manifested "when the teacher defines the program, plan and prepare the course, and continues throughout the supply of this, to guide students where necessary" (KERCKHOFFS, 2011, p. 24). If the culture of open thought is mobilized by OER integration movement as innovation for the democratization of access

Educação, Psicologia e Interfaces, Volume 4, Número 3, p. 1-18, Julho/Setembro, 2020.

ISSN: 2594-5343. DOI: 10.37444/issn-2594-5343.v4i3.257 
to knowledge (VON HIPPEL, 2005), it is understood the centrality of the special task of teachers (cognitive process and social relations). Making modes of production increasingly participatory and collaborative requires thinking the conditions and contours of teaching and the conceptions and pedagogical models involved (AMADOR; NOBRE; BARROS, 2016).

Thus, we highlight examples of resources and activities of the CU Master's course in Pedagogy of Elearning (MPEL) of the Open University of Portugal (UAb): Materials and Resources for eLearning in the academic year 2015-2016.

This CU had the structure of a Learning Agreement (Figure 2) contemplating: 1) Goals; 2) Skills; 3) Contents; 4) Methodology; 5) Features- Bibliography; 6) Learning Environment; 7) Sequence; 8) Evaluation; 9) Roadmap activities. This contract was made available to students from the beginning of the semester with explanations of the dynamics planned by the teacher and the appropriate schedule.

In this CU, the OER are the core content, developed in three subjects (Table 1):

\begin{tabular}{|l|l|}
\hline Issue I. Open Educational Resources & $\begin{array}{l}\text { 1. Some basic concepts connected to the notion of } \\
\text { "openness"; } \\
\text { 2. Origin, social, technical and educational } \\
\text { importance/impact; } \\
\text { 3. How to use and for what. Importance of } \\
\text { adaptation, design and sharing. }\end{array}$ \\
\hline $\begin{array}{l}\text { Issue II. Selection and Use of Open } \\
\text { Educational Resources }\end{array}$ & $\begin{array}{l}\text { 1. Repositories and other sources of onine OER; } \\
\text { 2. Research, analysis and selection of OER; } \\
\text { 3. Use of OER in a specific learning situation. }\end{array}$ \\
\hline $\begin{array}{l}\text { Issue III. Production of Open } \\
\text { Educational Resources }\end{array}$ & $\begin{array}{l}\text { 1. Tools and services that enable the creation and } \\
\text { publication of OER; } \\
\text { 2. Design, development and publication of a OER. }\end{array}$ \\
\hline
\end{tabular}

Table 1: Contents of the CU Materials and Resources for Elearning.

Source: Virtual Campus Portal - http://elearning.uab.pt.

While the integration of OER in the pedagogical design of virtual courses can represent itself an innovation, implemented experience, the process of authorship and coauthorship was planned that he might become possible to optimize the resources and activities making them: a) resources interactive potential; b) authored and co-authored marked by interactions and group work; c) materials produced educational and open technological nature (NOBRE; MALLMANN, 2016). Thus, students have access to various materials and activities carried out explicitly on the OER movement (Figure 2).

Educação, Psicologia e Interfaces, Volume 4, Número 3, p. 1-18, Julho/Setembro, 2020. ISSN: 2594-5343. DOI: 10.37444/issn-2594-5343.v4i3.257 


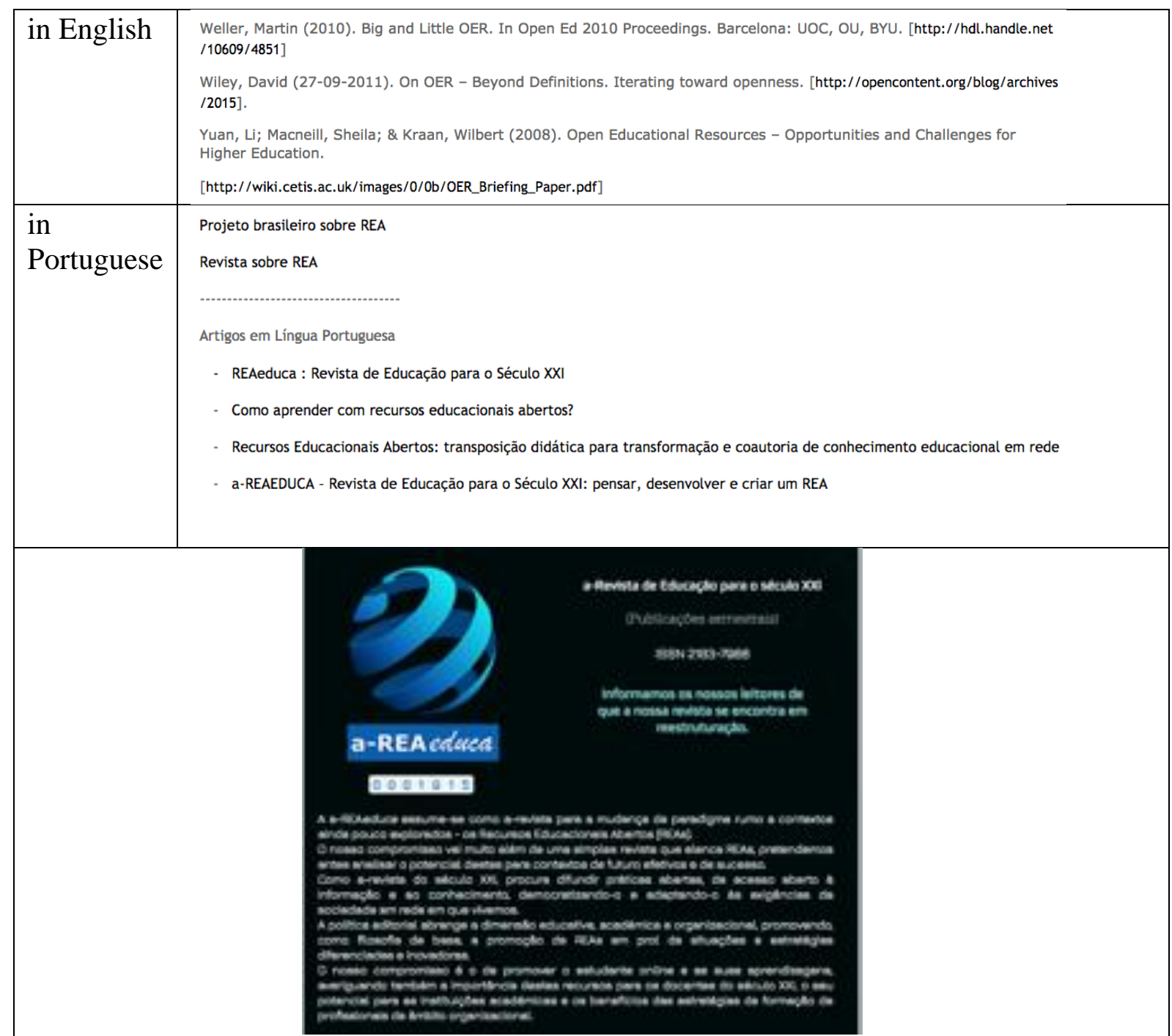

Figure 2: Some materials on OER - CU Materials and Resources for Elearning 20192020.

Source: Portal Virtual Campus - http://elearning.uab.pt

The pedagogical design of Resources and Activities (teaching materials) CU strengthened an open educational context. The priority was to enable an innovative approach in teaching practices in UAb that challenges students to develop research and appropriation of digital resources already developed by peers. Throughout CU, interactions in the Moodle forums (Figure 3) allowed to achieve success in collaborative curation, reuse, remixing, authored and coauthored.

Educação, Psicologia e Interfaces, Volume 4, Número 3, p. 1-18, Julho/Setembro, 2020.

ISSN: 2594-5343. DOI: 10.37444 /issn-2594-5343.v4i3.257 


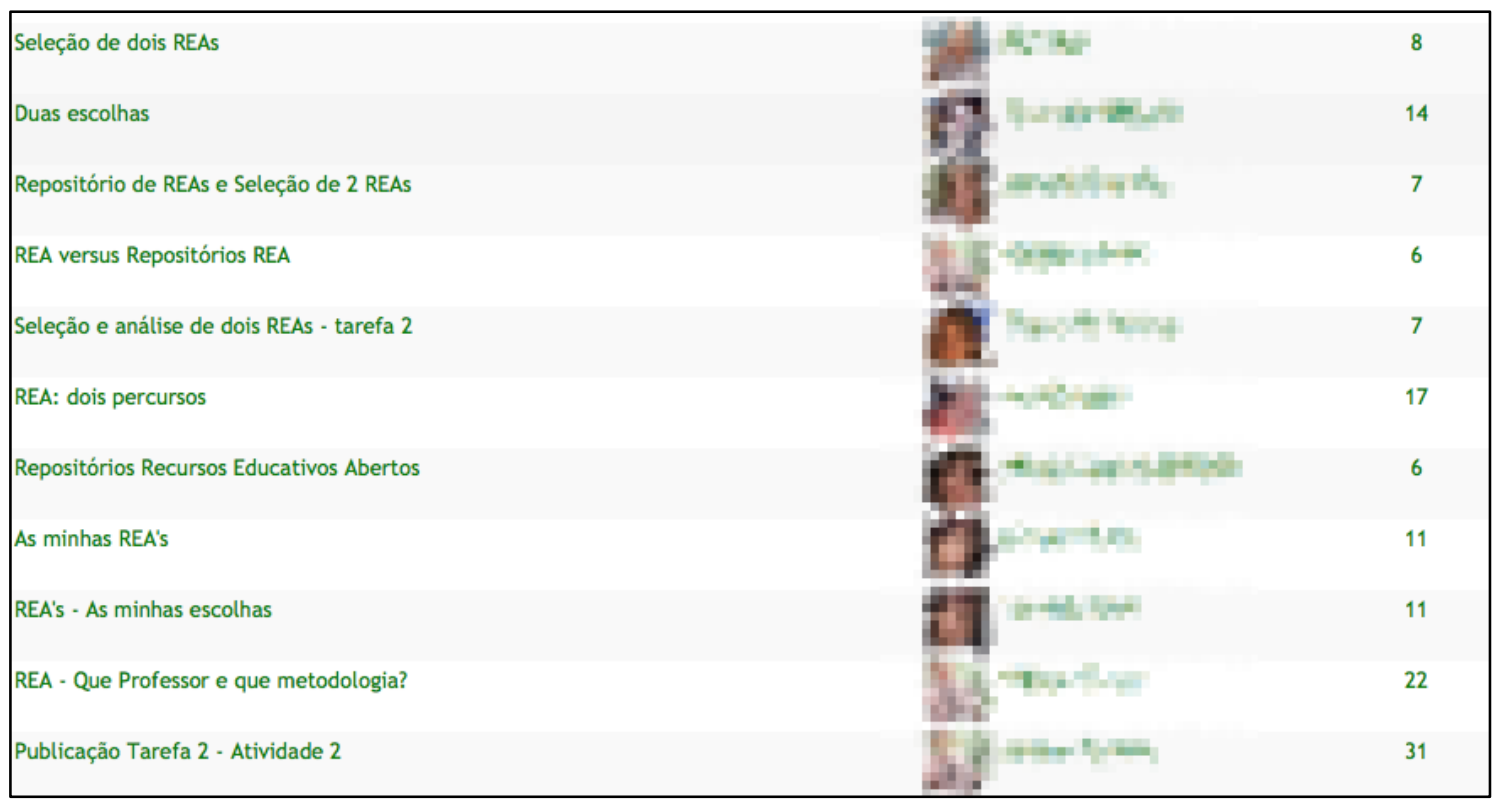

Figure 3: interactions in activity Forum 2 - CU Materials and Resources for Elearning 2019-2020.

Source: Portal Virtual Campus - http://elearning.uab.pt

The contents reconstructed collectively by the student under the guidance of teacher, can again be shared to enlarge its reuse in other academic and / or professional situations. Expanded to the conditions and pedagogical and technological contours, generating a network share of culture creation, adaptation and reuse of OER.

The pedagogical design, guided by the principles of TLP and OER generated theoretical and practical innovation in formal education. That is, both the teacher as the students became active and co-responsible for the strengthening of learning in collaborative networks centered in the process of re-creation of open content.

The pedagogical design produced innovative practices based on OER integration, strengthening the discussion of the materials and resources to eLearning. All this, within a social and cultural context marked by social media accessibility and digital convergence. Both the teaching practices as academic / scientific research need to move towards a more collaborative operation of production in line with emerging applications (PASTEUR Project 40A)

In the implemented experience, access, development and sharing among participants gave up due to the adoption of some essential aspects in open education:

a) unrestricted access to early versions of produced content;

Educação, Psicologia e Interfaces, Volume 4, Número 3, p. 1-18, Julho/Setembro, 2020.

ISSN: 2594-5343. DOI: $10.37444 /$ issn-2594-5343.v4i3.257 
b) organization of activities within a space / time by default academic semester schedule but flexible from the point of view of synchronous and asynchronous distance interaction mediated by technology;

c) composition of groups around themes determined by the CU program, but consistent with the learning objectives defined for each component;

d) logistics available to the technological support of both interactions as production, storage and sharing of new versions.

The participation of students throughout the semester was notorious and growing to the extent that they felt challenged to break with conceptions and traditional teaching learning practices. The pedagogical design of CU requires culture of participation of all from the beginning to the end of the semester is in discussions forum, whether in the preparation of thematic content.

Innovation in teaching design breaks with static assumptions of education mediated by networked technologies that in many cases, is neglecting the potential of digital platforms turning them into content repositories with little or no interactivity.

The Open Educational Practice (OEP) developed by integrating OER generated strong expectations for the development of the next CU marked by significant changes in the way students and teachers they access, create and recreate content and research methodologies, teaching and learning.

\section{outlooks \\ 2.2. The OER in the promotion of successful learning experiences - students}

In the 2019-2020 school year at CU, of course MPEL UAb, Materials and Resources for eLearning were enrolled 14 students. They participated throughout the semester and all ended successfully.

To allow another view of CU, as well as presented by the teacher, is exposed, then the experiments/experiences (the find out, assimilate, the sharing, the building) two students said CU in the same school year.

\subsection{Learning process}

With the presentation and discussion of the CU learning contract began an intense journey through the world of OER and experienced a process of learning quite challenging, thought-provoking and motivating.

Educação, Psicologia e Interfaces, Volume 4, Número 3, p. 1-18, Julho/Setembro, 2020.

ISSN: 2594-5343. DOI: $10.37444 /$ issn-2594-5343.v4i3.257 
Expectations about the dimensions of OER were high, particularly with regard to deepen knowledge and develop skills about their educational potential and dimensions that relate to $5 \mathrm{Rs}$ - retain, reuse, revise, remix and redistribute. It was found that the starting context for this discovery process were already consistent, particularly in awareness by students of the need to respect copyright, as well as the advantages that an open knowledge promotes both the pedagogical possibilities of the same either by the potential democratization of knowledge through the adoption of OER philosophy.

The CU learning process began with an intense reflection on the first business forum with students invited to discuss about the OER and build collaboratively, knowledge of the same, particularly with regard to its concept, nature, implementation and evaluation, through the reading of texts indicated by the teacher or resulting from research and personal reflection on this topic. The students participated actively and intensively in the discussions and launched reflection points scientifically based on the most current theories on the practices and key issues relating to OER. The discussion forum about the potential, challenges and opportunities of OER in the context of eLearning allowed a shared construction of knowledge, as well as the comments that were developed to products that were resulting from learning strategies of classmates who enabled this virtual learning community experienced an effective and successful knowledge of the OER philosophy.

It is noteworthy that the pedagogical strategy of using forums as spaces for interaction and debate throughout the process was essential to promote a highly collaborative and participatory learning, for each production, individual or collective, was submitted to assessment of classmates who, in turn, contributed in an essential way to the improvement of the work presented and to consolidate learning.

It's necessary to highlight the active presence of the teacher (Figure 4), which fostered a spirit set of active search for information and continuously overcome every challenge and unconditional support to promote this academic growth. 


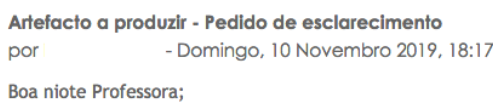

Estou a trabalhar na producao do artefacto, porem tenho algumas duvidas, nao percebi muito a orientacao para o trabalho. Os pontos:beneficios dos REA, REA no contexto educativo em Portugal ou outro pais, uso pedagógico dos REA, movimento Educação Aberta-REA, adoptar a filosofia REA, qualidade de um REA e estratégias para garantir a qualidade dos REAs sao temas a serem escolhidos para o desenvolvimento ou sao subtemas a ter em conta do desenvolvimento do tema escolhido pelomestrando?

Perdoe-me pela duvida, senhora professora.

Aluno 1901647: ।

Hiperligação direta | Editar | Apagar | Responder

Re: Artefacto a produzir - Pedido de esclarecimento

por Ana Nobre - Segunda, 11 Novembro 2019, 10:32

Caro Paulo,

não são temas nem subtemas, são apenas alguns caminhos por onde podem passear.

Por exemplo, a Educação Aberta, os REA em Moçambique podem ser um excelente trabalho. Este movimento já existe em Moçambique? se sim, óptimo, descrever a sua implementação; se não como poderia iniciar ...

Espero ter ajudado.

Ana Nobre

Hiperligação direta | Mensagem superior | Editar | Dividir discussão | Apagar | Responder

Figure 4 - student / teacher interaction in activity 2 Forum - CU Materials and Resources for Elearning 2019-2020. Source: Portal Virtual Campus -

\section{http://elearning.uab.pt}

\subsection{Goods of learning experiences}

As mentioned in this article, the pedagogical design of this unit enabled the effective development of a virtual learning community that experienced learning experiences and experienced not only the contact with theories about OER philosophy, but also the effective development of OER and products of different themes associated with them.

The diversity of activities designed for this $\mathrm{CU}$ allowed an intense experience of the dynamics of an open education. Since the writing of texts on the issue OER, the annotated bibliographies, research and sharing of sources/online OER repositories (with proper explanation for the selection), selection and use of OER (with foundation and development of learning scenarios that integrate), farm tools and services that enable the creation and publication of OER and to culminate this learning process, the design, development and publication of a OER.

Educação, Psicologia e Interfaces, Volume 4, Número 3, p. 1-18, Julho/Setembro, 2020. 
Thus, the task writing of texts on the issue OER (Figure 5) allowed to gain familiarity with the theme OER and rethink their potential, as well as issues concerning licensing, so fundamental to the operation of the OER philosophy.

E "Providers should create the conditions for a fair chance of learner success (Saide, n.d.).". Neste princípio surge o princípio da inclusão, do papel do educador, que segundo Dowes (2010) deve ser muito mais do que um transferidor passivo de conhecimentos recebidos aos alunos:

"Teachers, for example, need to learn how to work with and present user-generated content rather authoritative expert content -you can't just recite what's stated in the textbook. Teachers must demonstrate and foster a critical awareness in students, even at a young age through conversation and storytelling, promoting selfassessment and extending to the capacity to critically appraise and integrate material from multiple sources."

Figure 5 - Extract from a writing text of a student at CU Materials and Resources eLearning - 2019-2020.

Writing articles by students, who have studied the OER concept and its pedagogical dimension in eLearning contexts, promoted an in-depth knowledge of the OER philosophy. Here we can mention the two texts written by two students who are part of this article, a published online in the student's blog and one that, at the option of the author, was shared in activity Forum: Open Educational Resources - highlight for the future of learning ${ }^{1}$ (Pereira, 2015) and Challenges to the use of Open Educational Resources by Brazilian educators (Batista, 2015). The production of these items resulted in the first production of the students on the theme in question, therefore, as a learning strategy, his writing was essential to enable students to reflection and synthesis applied new knowledge, resulting in different experiences and very additional, which can be seen by the two productions exemplified.

Another point that marked the learning process was the contact with repositories and OER, which enabled the experimentation and implementation of 5R already mentioned. These products allowed investigate sources of information and experience different relief learning situations to the apprehension of the pedagogical potential of areas, particularly in eLearning contexts. At this stage of the process, there is the diversity 
of resources researched and intense debate in the forums, considering the diverse OER formats and also the various resources available online that are confused with OER, without, however, meet all the fundamental principles of this philosophy. Moreover, the activities carried out, in particular the selection of OER and planning of a proposed educational activity that use it, set up a first opportunity of educational application of a OER considering all its potential as use permission of selected resource.

At this point of this article, are presented in more detail the products that resulted from the last thematic unit CU - Open Educational Resources Production - by the intensity with which it was experienced either by the joint capacity of the powers provided for development at $\mathrm{CU}$ and the OER that resulted from this activity.

The challenge was to develop a OER to be presented in a virtual exhibition on the theme "The present and future of online education: prospects and challenges".

The activity would have to be developed in four distinct phases: a) definition of the work area; b) planning activity; c) preparation of the OER; d) writing a critical reflection of the whole process.

Both students have chosen to run the pairs towards the goals of optimization, collaborative work and a construction of the richest and enriching knowledge.

We presented below (Figure 6) an example of the product presented by a student: a video about Open Education and Face-to-face Education

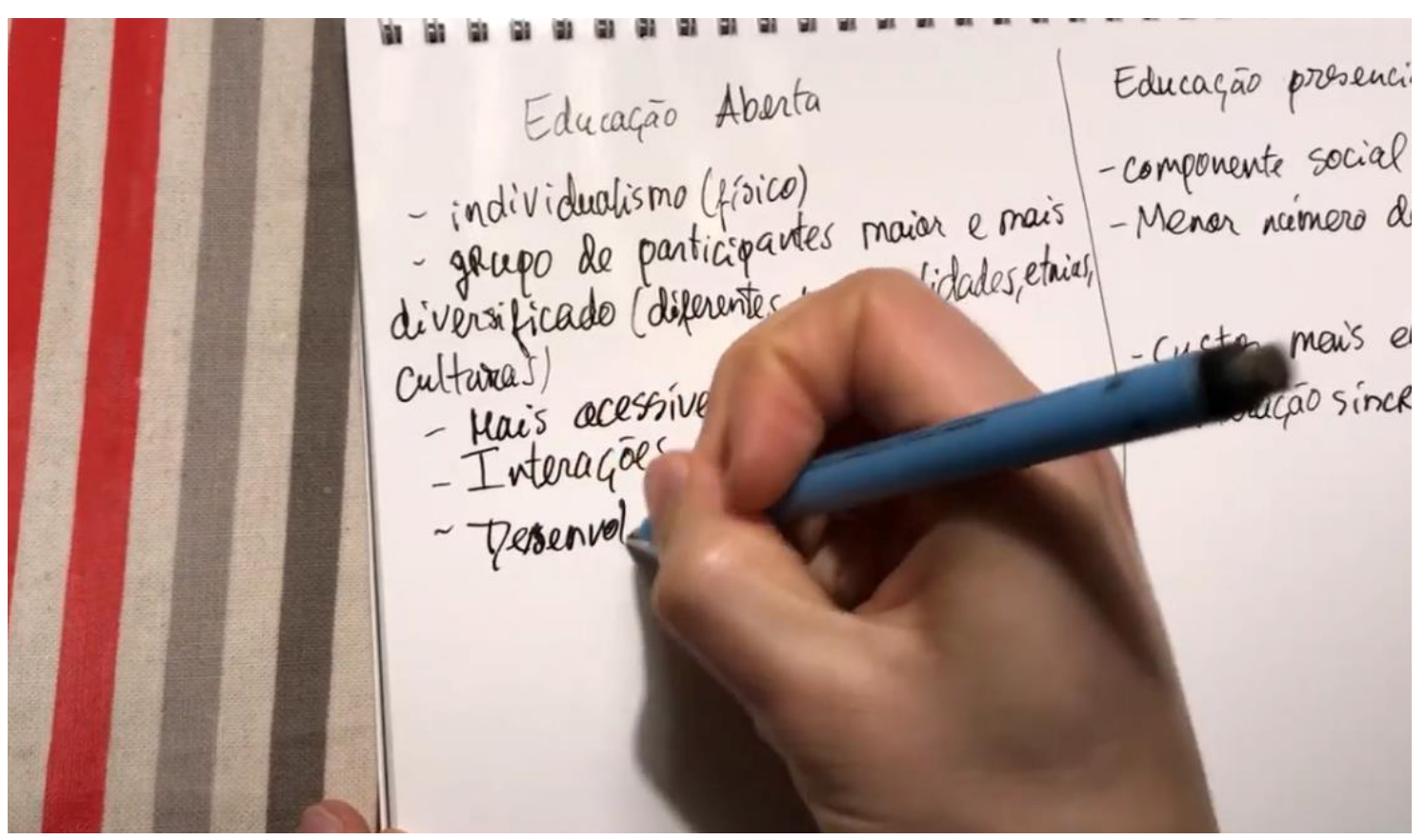

Educação, Psicologia e Interfaces, Volume 4, Número 3, p. 1-18, Julho/Setembro, 2020.

ISSN: 2594-5343. DOI: 10.37444/issn-2594-5343.v4i3.257 
Figure 6: Presentation of a student on the use of two OER in learning activities.

Source: https://youtu.be/5H3rvA1xIGU

At this point of this article, are presented in more detail the products that resulted from the last thematic unit CU - Open Educational Resources Production - by the intensity with which it was experienced either by the joint capacity of the powers provided for development at CU and the OER that resulted from this activity.

The challenge was to develop a OER to be presented in a virtual exhibition on the theme "The present and future of online education: prospects and challenges".

The activity would have to be developed in four distinct phases: a) definition of the work area; b) planning activity; c) preparation of the OER; d) writing a critical reflection of the whole process.

Both students have chosen to run the pairs towards the goals of optimization, collaborative work and a construction of the richest and enriching knowledge.

One of the authors presented as a final product of the activity the development of an online magazine - REAeduca - Journal of Education for the twenty-first Century. All the online page building process, graphics, articles, infographics, promotional teaser and promotion of the magazine page on Facebook ${ }^{\circledR}$ social network is the work of the two group members (except the publication of a colleague invited to an article on the subject in focus).

The official REAeduca site can be found at http://reaeduca.wix.com/reaeduca address (Figure 7) and the public page on the social network said, to promote and stimulate the magazine at http://www.facebook.com/reaeduca/.

\subsection{Personal and professional impact}

The student experience that CU has exceeded initial expectations, particularly in the personal and professional growth that occurred. Noteworthy is the access to a more detailed and scientifically based knowledge, largely achieved part actively during the research activities and discussion with peers as well as the awareness of the importance of the democratization of knowledge and capabilities that OER philosophy embraces with regard to the promotion of eLearning quality and successfully. 
We denote the starting contexts with which we started the CU were agreed, but also superficial, allowing stress the importance of the pedagogical design of the CU and the pedagogical approach to teaching, to the active and collaborative construction of an effective knowledge of the potential of OER philosophy.

The frequency at $\mathrm{CU}$ enabled the development of digital skills and contact with tools, repositories and OER strategies that are of significant importance to our attitude to the dissemination of information on the network, copyrights and the issues that arise with the licensing of different resources available to the network interaction.

It is essential to emphasize the professional impact that $\mathrm{CU}$ promoted in students. Both students work with Education and reinforce the potential for OER to and from all education and an effective application of the topics covered during the semester. All the knowledge gained has been translated into powers beyond the context of this master and internalized in their professional practices, highlighted the selection of skills, adaptation and publication of online educational resources, becoming more conscious for both students the minimum requirements for production and sharing OER. It is relevant to say that the change goes beyond the personal attitude to the available resources, particularly in the online context, but both adopted after this experience, an active stance multiplication OER philosophy in their professional contexts.

A concrete example of this transformation, one of the authors who operates a professional education institution in Brazil, started a movement to discuss institutional actions in order to contribute to the awareness of the teams on the use of online resources in the creation of educational materials, and to promote activities with the management teams of the importance of defining usage policies and sharing of resources produced by the institution, contributing to the virtuous cycle of the OER movement.

\section{CONCLUSION}

The main scientific results and technological and educational innovations that can be detached from the experience are analyzed the impact of OER in teaching design in virtual environments and its role for an open education, effective and successful.

In the educational context, teachers (regardless of their more or less active roles in technology co-development of OER) have the challenge of creating possibilities of integration of educational technology network in the teaching-learning process and also in research activities. In other words, this means that in addition to the theoretical 
discussion of the principles of open education, are becoming necessary concrete practices that generate wider impacts on reuse.

The academic community that argues in favor of the open education movement needs to communicate with more confidence innovative pedagogical practices from the point of view of teaching (co) authored for integration of OER in online education. If, on the one hand, the concepts and theoretical productions are moving, on the other, there is still much to be done to consolidate the OER, in terms of implementation of teaching practices, institutionalization of training programs to expand technological and pedagogical fluency of teachers infrastructure open storage logistics for sharing and public policy.

\section{REFERENCES}

ALBRIGHT, P. Open Educational Resources. Open Content for Higher Education. Final Forum Report. Paris: UNESCO, 2005. Disponível em: http://www.unesco.org/iiep/virtualuniversity/forumshome.php?queryforums_id=3 Acesso em: 20 fev. 2020

AMADOR, F., Nobre, A., Barros, D. Towards a model of a didactic of eLearning: an application to education for sustainable development, Handbook of Research on Engaging Digital Natives in Higher Education Settings, IGI GLOBAL, 2016. DOI: 10.4018/978-1-5225-0039-1.ch019.

COMISSÃO EUROPEIA. Opening up Education -a proposal for an European Initiative to enhance education and skills development through new technologies. Bruxelas: Comissão Europeia, 2013. Disponível em: http://ec.europa.eu/smartregulation/impact/planned_ia/docs/2013_eac_003_opening_up_education_en.pdf.

Acesso em: 10 fev. 2020

CONOLE, G. Fostering social inclusion through open educational resources (OER). In: Journal Distance Education, 33(2), 2012, 131-134. Disponível em: http://www.tandfonline.com/doi/abs/10.1080/01587919.2012.700563\#.Um8G-4up1rx.

Acesso em: 12 dez. 2019

EHLERS, U. D. From Open Educational Resources to Open Educational Practices. eLearning Papers, 23(March), 1-8, 2011. Disponível em: http://www.elearningeuropa.info/files/media/media25231.pdf. Acesso em: $12 \mathrm{dez} .2019$

GARRISON, D. R.; ANDERSON, T.; ARCHER, W. Critical Inquiry in a Text-Based Environment: Computer Conferencing in Higher Education. In: The Internet and Higher Education, 2(2-3), 2000, 1-34. Disponível em: 
http://auspace.athabascau.ca/bitstream/2149/739/1/critical_inquiry_in_a_text.pdf Acesso em: 12 dez. 2019

GOMES, A.A.; TAVARES, J. Pesquisa e gestão da informação e sucesso académico no ensino superior. ln J. Tavares, \& R. A. Santiago (orgs.), Ensino Superior: (ln)sucesso académico. Porto: Porto Editora, ClDlnE, 2002.

KERCKHOFF, M. T. (2011). O Modelo de Comunidade de Investigação e a Construção da Aprendizagem Significativa On-line. In Revista EducaOnline. 5(2 may/august), 2011.

MACHADO, C.; ALMEIDA, L. S. Vivências académicas: Análise diferencial em estudantes do $1^{\circ}$ e $4^{\circ}$ anos do ensino superior. ln J. Tavares, \& R. A. Santiago (orgs.), Ensino Superior: (In)sucesso académico. Porto: Porto Editora, CIDlnE, 2000.

MULDER, A. Oen Educational Resources and the Role of the University. In EDUCAUSE Review Magazine, Volume 46, Number 5, September/October 2011. Disponível em: https://er.educause.edu/articles/2011/9/educause-review-magazinevolume-46-number-5-septemberoctober-2011 Acesso em: 09 fev. 2020.

NOBRE, A.; MALLMANN, E. Recursos Educacionais Abertos: transposição didática para transformação e coautoria de conhecimento educacional em rede. In Indagatio Didactica, vol. $8(2)$ julho $2016 . \quad$ Disponível em: http://revistas.ua.pt/index.php/ID/article/view/4028 Acesso em: 12 dez. 2019

PAIVA, M. O. A. Abordagens à aprendizagem e abordagens ao ensino: Uma aproximação à dinâmica do aprender no secundário. Braga: Universidade do Minho, 2007

PEREIRA, H. Open Educational Resources. In: highlight for the future of learning, 2015. Disponível em: http://mpelianismo.wordpress.com/2015/11/19/recursoseducacionais-abertos-principio-orientador-para-a-aprendizagem-do-futuro-artigo/

Acesso em: 21 jan. 2020.

Projeto Pasteur40A. Retrieved from http://www.pasteur4oa.eu/

ROSÁRIO, P. Estudar o estudar: (Des)venturas do Testas. Porto: Porto Editora, 2004

ROSÁRIO, P.; MOURÃO, R.; SALGADO, A. Trabalhar e estudar sob a lente dos processos estratégicos de auto-regulação da aprendizagem. Psicologia, Educação $e$ Cultura, 2006, 10,77- 88.

SANTIAGO, R. A. Aprendizagem organizacional nas instítuições de ensino superior. In J. Tavares, \& R. A. Santiago (orgs.), Ensino Superior: (ln)sucesso académico. Porto: Porto Editora, 2000

SCHUNK, D. H.; ZIMMERMAN, B. J. Self regulationin education: Retrospect and prospect. In, D. H. Schunk, \& Zimmerman (eds.), Self-regulation of learning and performance: Issues and educational applìcations, 1994 (pp. 305-314). Hillsdale, NJ: Lawrence Erlbaum. 
SCHUNK, D. H.; ZIMMERMAN, B. J. Conclusions and future directions for academic interventions. Ln: D. H. Schunk, \& Zimmerman (eds.), Seff-regulation learning. From teaching to self-reflective practice, 1998 (pp.225-234). Hillsdale, NJ: Lawrence Erlbaum.

SOUZA, E.B. Challenges to the use of Open Educational Resources by Brazilian educators. Unpublished manuscript, 2015.

VON HIPPEL, E. Democratizing Innovation. Cambridge, Massachusetts: The MIT Press, 2005.

WILEY, D.; HILTON J. (2009). Openness, Dynamic Specialization, and the Disaggregated Future of Higher Education. In The International Review of Research in Open and Distance Learning, 2009, 10(5). Disponível em: http://www.irrodl.org/index.php/irrodl/article/view/768 Acesso em: 09 fev. 2020

YUAN, L; POWELL, S. (2013). MOOCs and Open Education: Implications for Higher Education. JISC: CETIS, 2013. Disponível em: http://publications.cetis.ac.uk/2013/667 Acesso em: 12 dez. 2019.

ZIMMERMAN, B. J.; BONNER, S.; KOVACH, R. Developing self-regulated learners: Beyond achievement to self-eflcacy. Washington, DC: American Psychological Association, 1996.

ZIMMERMAN, B. J. (2002). Becoming a self-regulated learner: An overview. In Theory into Practice, 2002, 41, 64-70.

\section{Credenciais da autora}

NOBRE, Ana. Laboratório de Ensino a Distância e eLearning (LE@D), Universidade Aberta / Portugal , graduada em Didática das Línguas e Culturas Estrangeiras pela Université Sorbonne, Paris, France. Orcid: 0000-0002-9902-1850. E-mail:

Ana.Nobre@uab.pt

Endereço para correspondência: Ana Nobre. Rua do triângulo Vermelho $n^{\circ} 27-1^{\circ}$ 1170-374 Lisboa, Portugal .E-mail: Ana.Nobre@uab.pt

Como citar este artigo (Formato ABNT): NOBRE, Ana. Share Knowledge, Participate In Open Education And Create Oer . Educação, Psicologia e Interfaces, v. 4, n.2, p. 1-18, 2020.

Recebido: $25 / 04 / 2020$.

Aceito: 10/06/2020. 